\title{
Note on stability of the Cauchy equation - an answer to a problem of Th. M. Rassias
}

\author{
JANUSZ BRZDȨK
}

\section{ABSTRACT.}

We give an answer to a problem formulated by Th. M. Rassias in 1991 concerning stability of the Cauchy equation; we also disprove a conjecture of Th. M. Rassias and J. Tabor. In particular, we present a new method for proving stability results for functional equations.

\section{REFERENCES}

[1] Aoki, T., On the stability of the linear transformation in Banach spaces, J. Math. Soc. Japan, 2 (1950), 64-66

[2] Baker, J. A., The stability of certain functional equations, Proc. Amer. Math. Soc., 112 (1991), 729-732

[3] Bourgin, D. G., Approximately isometric and multiplicative transformations on continuous function rings, Duke Math. J., 16 (1949), 385-397

[4] Bourgin, D. G., Classes of transformations and bordering transformations, Bull. Amer. Math. Soc., 57 (1951), 223-237

[5] Brzdęk, J., A note on stability of additive mappings, in Stability of Mappings of Hyers-Ulam Type (Th. M. Rassias, J. Tabor, Eds.), Hadronic Press, Inc., Florida, 1994, 19-22

[6] Brzdęk, J., On a method of proving the Hyers-Ulam stability of functional equations on restricted domains, Austral. J. Math. Anal. Appl., 6 (2009), No. 1, Art. 4, 10 pp

[7] Brzdęk, J., Chudziak, J. and Páles, Z., A fixed point approach to stability of functional equations, Nonlinear Anal., $74(2011), 6728-6732$

[8] Brzdęk, J. and Ciepliński, K., A fixed point approach to the stability of functional equations in non-Archimedean metric spaces, Nonlinear Anal., 74 (2011), 6861-6867

[9] Cădariu, L., Găvruța, L. and Găvruţa, P., Fixed points and generalized Hyers-Ulam stability, Abstr. Appl. Anal., 2012 (2012), Art. ID 712743, 10 pp

[10] Cădariu, L. and Radu, V., Fixed point methods for the generalized stability of functional equations in a single variable, Fixed Point Theory Appl., 2008 (2008), Art. ID 749392, 15 pp

[11] Dhombres, J. and Ger, R., Équations de Cauchy conditionnelles, C. R. Acad. Sc. Paris Sér. A, 280 (1975), 513-515

[12] Dhombres, J. and Ger, R., Conditional Cauchy equations, Glasnik Mat. III, 13 (1978), No. 33, 39-62

[13] Forti, G.-L., Comments on the core of the direct method for proving Hyers-Ulam stability of functional equations, J. Math. Anal. Appl., 295 (2004), 127-133

[14] Forti, G.-L., Elementary remarks on Ulam-Hyers stability of linear functional equations, J. Math. Anal. Appl., 328 (2007), 109-118

[15] Forti, G.-L. and Sikorska, J., Variations on the Drygas equation and its stability, Nonlinear Anal., 74 (2011), 343-350

[16] Gajda, Z., On stability of additive mappings, Int. J. Math. Math. Sci., 14 (1991), 431-434

[17] Găvruța, P., A generalization of the Hyers-Ulam-Rassias stability of approximately additive mappings, J. Math. Anal. Appl., 184 (1994), 431-436

[18] Găvruța, P., On the approximately linear mappings, Bull. Appl. Math. (Budapest), 80 (1996), 317-322

[19] Găvruța, P., On the Hyers-Ulam-Rassias stability of the quadratic mappings, Nonlinear Funct. Anal. Appl., 9 (2004), 415-428

[20] Găvruța, P., On the Hyers-Ulam-Rassias stability of mappings, in Recent Progress in Inequalities, (G. V. Milovanovic, ed.), Kluwer Academic Publishers, 1998, 465-469

Received: 15.05.2012; In revised form: 05.01.2013; Accepted: 21.06.2013

2010 Mathematics Subject Classification. 39B62, 39B82.

Key words and phrases. Hyers-Ulam-Rasssias stability, Cauchy equation, additive function. 
[21] Ger, R., On functional inequalities stemming from stability equations, in General Inequalities 6, (W. Walter, Ed.), 227-240, ISNM 103, Birkhäuser, Basel, 1992

[22] Hyers, D. H., On the stability of the linear functional equation, Proc. Natl. Acad. Sci. U.S.A., 27 (1941), 222-224

[23] Hyers, D. H., Transformations with bounded mth differences, Pacific J. Math., 11 (1961), 591-602

[24] Hyers, D. H., Isac, G. and Rassias, Th. M., Stability of Functional Equations in Several Variables, Birkhäuser, Boston, 1998

[25] Hyers, D. H., Isac, G. and Rassias, Th. M., On the asymptoticity aspect of Hyers-Ulam stability of mappings, Proc. Amer. Math. Soc., 126 (1998), 425-430

[26] Hyers, D. H. and Rassias, Th. M., Approximate homomorphisms, Aequationes Math., 44 (1992), 125-153

[27] Hyers, D. H. and Ulam, S. M., On approximate isometries, Bull. Amer. Math. Soc., 51 (1945), 288-292

[28] Hyers, D. H. and Ulam, S. M., Approximate isometries of the space of continuous functions, Ann. of Math., 48 (1947), No. 2, 285-289

[29] Hyers, D. H. and Ulam, S. M., Approximately convex functions, Proc. Amer. Math. Soc., 3 (1952), 821-828

[30] Isac, G. and Rassias, Th. M., On the Hyers-Ulam stability of $\psi$-additive mappings, J. Approx. Theory, 72 (1993), $131-137$

[31] Isac, G. and Rassias, Th. M., Stability of $\psi$-additive mappings: Applications to nonlinear analysis, Int. J. Math. Math. Sci., 19 (1996), 219-228

[32] Jabłoński, W., Stability of homogeneity almost everywhere, Acta Math. Hungar., 117 (2007), 219-229

[33] Jung, S.-M., Hyers-Ulam-Rassias stability of functional equations, Dynam. Systems Appl., 6 (1997), 541-566

[34] Jung, S.-M., A fixed point approach to the stability of isometries, J. Math. Anal. Appl., 329 (2007), 879-890

[35] Jung, S.-M., Hyers-Ulam-Rassias Stability of Functional Equations in Nonlinear Analysis, Springer Optimization and Its Applications, vol. 48, Springer, New York-Dordrecht-Heidelberg-London, 2011

[36] Jung, S.-M. and Kim, T.-S., A fixed point approach to the stability of the cubic functional equation, Bol. Soc. Mat. Mexicana, 12 (2006), No. 3, 51-57

[37] Jung, S.-M., Kim, T.-S. and Lee, K.-S., A fixed point approach to the stability of quadratic functional equation, Bull. Korean Math. Soc., 43 (2006), 531-541

[38] Jung, Y.-S. and Chang, I.-S., The stability of a cubic functional equation and fixed point alternative, J. Math. Anal. Appl., 306 (2005), 752-760

[39] Kominek, Z., On a local stability of the Jensen functional equation, Demonstratio Math., 22 (1989), 499-507

[40] Kuczma, M., An Introduction to the Theory of Functional Equations and Inequalities, Cauchys Equation and Jensens Inequality, Birkhuser, 2nd edition, 2009

[41] Losonczi, L., On the stability of Hosszú's functional equation, Results Math., 29 (1996), 305-310

[42] Mirzavaziri, M. and Moslehian, M. S., A fixed point approach to stability of a quadratic equation, Bull. Braz. Math. Soc., New Series, 37 (2006), 361-376

[43] Moszner, Z., On the stability of functional equations, Aequationes Math., 77 (2009), 33-88

[44] Pólya, Gy. and Szegö, G., Aufgaben und Lehrsätze aus der Analysis I, Verlag von Julius Springer, Berlin, 1925

[45] Radu, V., The fixed point alternative and the stability of functional equations, Fixed Point Theory, 4 (2003), 91-96

[46] Rassias, Th. M., On the stability of the linear mapping in Banach spaces, Proc. Amer. Math. Soc., 72 (1978), 297-300

[47] Rassias, Th. M., Problem, Aequationes Math., 39 (1990), 309

[48] Rassias, Th. M., On a modified Hyers-Ulam sequence, J. Math. Anal. Appl., 158 (1991), 106-113

[49] Rassias, Th. M., On the stability of the quadratic functional equation and its applications, Studia Univ. BabeşBolyai Math., 43 (1998), No. 3, 89-124

[50] Rassias, Th. M., The problem of S.M. Ulam for approximately multiplicative mappings, J. Math. Anal. Appl., 246 (2000), 352-378

[51] Rassias, Th. M., On the stability of functional equations and a problem of Ulam, Acta Appl. Math., 62 (2000), 23-130

[52] Rassias, Th. M., On the stability of functional equations in Banach spaces, J. Math. Anal. Appl., 251 (2000), 264-284

[53] Rassias, Th. M. and Šemrl, P., On the behavior of mappings which do not satisfy Hyers-Ulam stability, Proc. Amer. Math. Soc., 114 (1992), 989-993

[54] Rassias, Th. M. and Šemrl, P., On the Hyers-Ulam stability of linear mappings, J. Math. Anal. Appl., 173 (1993), 325-338

[55] Rassias, Th. M. and Tabor, J., What is left of Hyers-Ulam stability?, J. Nat. Geometry, 1 (1992), 65-69

[56] Rassias, Th. M. and Tabor, J., On approximately additive mappngs in Banach spaces, in Stability of Mappings of Hyers-Ulam Type (Th. M. Rassias, J. Tabor, Eds.), Hadronic Press, Palm Harbor, 1994, 127-134

[57] Rätz, J., On approximately additive mappings, in General Inequalities 2 (E. F. Beckenbach, Ed.), Birkhäuser, Basel, 1980, 233-251 
[58] Šemrl, P., The stability of approximately additive mappings, in Stability of Mappings of Hyers-Ulam Type, (Th. M. Rassias, J. Tabor, Eds.), Hadronic Press, Palm Harbor, 1994, 135-140

[59] Sikorska, J., On a direct method for proving the Hyers-Ulam stability of functional equations, J. Math. Anal. Appl., 372 (2010), 99-109

[60] Skof, F., On the stability of functional equations on a restricted domain and related topics, in Stability of Mappings of Hyers-Ulam Type, (Th. M. Rassias, J. Tabor, Eds.), Hadronic Press, Palm Harbor, 1994, 141-151

[61] Ulam, S. M., Problems in Modern Mathematics, Science Editions, John-Wiley \& Sons Inc., New York, 1964

DEPARTMENT OF MATHEMATICS

Pedagogical University

PODCHORA̧Ż̇YCH 2, PL-30-084 KRAKÓW, POLAND

E-mail address: jbrzdek@up.krakow.pl 